\title{
Salvianolic acid B and danshensu induce osteogenic differentiation of rat bone marrow stromal stem cells by upregulating the nitric oxide pathway
}

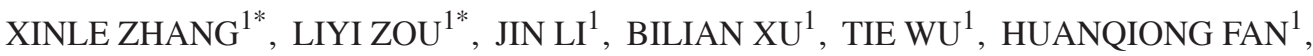 \\ WEIMING XU ${ }^{1}$, WEIMIN YAO ${ }^{2}$, YAJUN YANG ${ }^{1}$, YUYU LIU ${ }^{1}$ and LIAO CUI ${ }^{1,3}$
}

${ }^{1}$ Department of Pharmacology, Guangdong Medical University; ${ }^{2}$ Department of Respiratory Medicine, The Affiliated Hospital of Guangdong Medical University; ${ }^{3}$ Guangdong Key Laboratory for Research and Development of Natural Drugs, Guangdong Medical University, Zhanjiang, Guangdong 524023, P.R. China

Received January 22, 2016; Accepted February 10, 2017

DOI: $10.3892 / \mathrm{etm} .2017 .4914$

\begin{abstract}
The aim of the present study was to investigate the effect of salvianolic acid B (Sal B) and danshensu (DSU) on the osteogenic differentiation of bone marrow mesenchymal stem cells (MSCs) and the mechanisms of the effects. The osteogenic differentiation of MSCs in culture was assessed by measuring alkaline phosphatase (ALP) activity, osteocalcin (OCN) production, nitric oxide (NO) production and the mRNA expression levels of osteoprotegerin (OPG) and its ligand by MSCs. MSCs were successfully induced to differentiate into osteoblasts and adipocytes. Sal B and DSU increased the ALP activity and the production of OCN in the absence of an ossification inducer. The increase in ALP activity was more pronounced when induction was combined with the osteogenic inducer, Sal B, which enhanced the expression of OPG; however, Sal B reduced the expression of receptor activator of nuclear factor- $\kappa \mathrm{B}$ ligand (RANKL) by MSCs. Sal B reversed the inhibitory effect of N-nitro L-arginine methylester on the MSCs and increased ALP activity, OCN content and the $\mathrm{OPG} / \mathrm{RANKL}$ ratio. Based on these results, it was concluded that Sal B increases the osteogenic differentiation of MSCs, most likely by regulating the nitric oxide pathway.
\end{abstract}

\section{Introduction}

Long-term treatment with Glucocorticoids used for inflammatory and autoimmune diseases may lead to

Correspondence to: Professor Liao Cui or Professor Yuyu Liu, Department of Pharmacology, Guangdong Medical University, 2 Wenmingdon Road, Zhanjiang, Guangdong 524023, P.R. China

E-mail: cuiliao@163.com

E-mail: liuyuyu77@163.com

*Contributed equally

Key words: salvianolic acid B, danshensu, bone marrow mesenchymal stem cells, nitric oxide, osteoporosis glucorcoticoid-induced osteoporosis. Currently, the administration of glucorcoticoid-induced osteoporosis medications include calcium, vitamin D, bisphosphonates, raloxifene, parathyroid hormone (PTH), hormone replacement and calcitonin. These drugs do not Solve the detrimental effect of Glucocorticoid on bone marrow fat metabolism or the circulatory system. Therefore, further studies on these Glucocorticoid induced effects may lead to the development of a novel treatment to treat and prevent glucorcoticoid-induced osteoporosis. Salvia miltiorrhiza water extract is effective at preventing glucocorticoid-induced osteoporosis in rats (1). S. miltiorrhiza water extract and danshensu (DSU), one of its active components, promote the osteogenic differentiation of bone marrow mesenchymal stem cells (MSCs) and also inhibit their adipogenic differentiation (1). Salvianolic acid B (Sal B), the main water-soluble component of $S$. miltiorrhiza, may help to prevent atherosclerosis, protect cardiac muscle and reduce blood pressure (2). The antihypertensive effects of Sal B depend on the upregulation of kinin-releasing enzymes, prostaglandin (3) and nitric oxide (NO) by endothelial cells (4). Prostaglandins and NO are important molecules in the pathophysiology of osteoporosis; however, the effects of Sal B on bone pharmacology remain unknown. Previous work has demonstrated that Sal B is able to prevent bone loss by stimulating osteogenesis and bone marrow angiogenesis in prednisone-treated rats (1). The aim of the present study was to determine the anti-osteoporosis effects of Sal B and the potential mechanisms for those effects related to the NO pathway, as well as to provide experimental evidence for the anti-osteoporosis effects of Sal B.

\section{Materials and methods}

Reagents. Sal B (111562-200403) and DSU (110855-200304) were provided by the National Institute for the Control of Pharmaceutical and Biological Products (Beijing, China). Dulbecco's modified Eagle medium (DMEM) was purchased from Gibco (Thermo Fisher Scientific, Inc., Waltham, MA, USA). $\beta$-glycerophosphate, vitamin $\mathrm{C}$, dexamethasone, trypsin, 3-(4,5-dimethylthiazol-2-yl)-2,5-diphenyltetrazolium 
bromide, para-nitrophenylphosphate (PNPP), prostaglandin E2 and N-nitro L-arginine methyl ester (L-NAME) were purchased from Alexis Biochemicals (Enzo Life Sciences, Inc. Farmingdale, NY, USA). Hydroxyproline determination kits (Nanjing Jiancheng Bioengineering Institute, Nanjing, China), osteocalcin (OCN) radioimmunoassay kits (Tianjin Jiuding Medical Biological Engineering Co., Ltd., Tianjin, China) and Access reverse transcription-polymerase chain reaction (RT-PCR) kits (Promega Corp., Madison, WI, USA) were also purchased. All PCR primers (Table I) were synthesized by the Shanghai Biological Engineering Company (Shanghai, China).

Animals. A total of 12, 4-week-old Specific pathogen-free (SPF) Sprague-Dawley rats (100 \pm 20 g; 50:50 male: female) were obtained from the Experimental Animal Center of Guangdong Medical University (Foshan, China). Animal quality certification was provided by Guangdong Province (2003A030), as was an experimental animals, environment and facilities certification (2003B012). The animals were housed in a temperature and humidity controlled environment $\left(22-24^{\circ} \mathrm{C}, 55 \pm 5 \%\right.$ humidity and a standard $12 \mathrm{~h}$ light/dark cycle), and supplied with food and water ad libitum. A total of 12 rats were utilized in this study. All experimental protocols were approved by the Guangdong Medical University Animal Care and Use Committee (Zhanjiang, China).

Instruments. Various instruments were used for the present study, including a NAPCO carbon dioxide incubator (5420-1; Precision Scientific of America, Waltham, MA, USA), an XD-101 inverted phase contrast microscope (Guangdian LLC, Nanjing, China), a microplate reader (Bio-ELx-800; Cole-Parmer, Vernon Hills, IL, USA), a $\gamma$-counter (1470WIZARD; PerkinElmer, Inc., Waltham, MA, USA), a MSI Trace vibrator (IKA GmbH, Königswinter, Germany), a PCR System (9600 GeneAmp; PerkinElmer, Inc.), type DYY-5 stable voltage electrophoresis apparatus (Six One Instrument Factory, Beijing, China) and type WD-9403C ultraviolet analyzer (Six One Instrument Factory).

Osteogenic induction of MSCs. Passage three MSCs were cultured in high glucose Dulbecco's modified Eagle's medium (DMEM) supplemented with $10 \%$ fetal bovine serum (FBS; Gibco; Thermo Fisher Scientific, Inc.) and 1\% antibiotic cocktail $(10,000 \mu \mathrm{g} / \mathrm{ml}$ penicillin $\mathrm{G}$ sodium and $10,000 \mu \mathrm{g} / \mathrm{ml}$ streptomycin sulfate). The isolation and proliferation of rMSCs was performed according to previously described methods (5). Briefly, all 12 of the4-week-oldSPF Sprague-Dawley rats (100 g) were sacrificed by cervical dislocation and the bone marrow was harvested by flushing their femoral cavities with PBS. Bone marrow cells were prepared by gradient centrifugation at $900 \mathrm{x} \mathrm{g}$ for $30 \mathrm{~min}$ on a Percoll-Paque gradient (Amersham Pharmacia Biotech, Inc., Piscataway, NJ, USA) at a specific gravity of $1.073 \mathrm{~g} / \mathrm{ml}$. The low-density mononuclear cells were washed twice in Hanks' balanced salt solution and cultured in DMEM supplemented with $10 \%$ FBS and $1 \%$ antibiotic $(10,000 \mathrm{U} / \mathrm{ml}$ penicillin $\mathrm{G}$ sodium, $10,000 \mu \mathrm{g} / \mathrm{ml}$ streptomycin sulfate) at $37^{\circ} \mathrm{C}$ in a humidified atmosphere containing $5 \% \mathrm{CO}_{2}$. The medium was changed every 3 to 4 days to remove the non-adherent hematopoietic cells. The adherent cell population was expanded and passaged every 12 to 14 days. All cells used for the experiments have been through three passages. To identify the abilities of rMSCs with regard to osteogenesis and adipogenesis, the following studies were preformed. Micrographs of osteoblasts isolated from the 4-week-old SPF SD rats in vitro were obtained on day 3, 4 and 7 under inverted phase-contrast microscope at x200 magnification.

For induction, the culture medium was changed to osteoblast medium (OBM), composed of high glucose DMEM supplemented with $50 \mu \mathrm{g} / \mathrm{ml} \mathrm{L}$-ascorbic acid, $10^{-2} \mathrm{M}$ $\beta$-glycerophosphate and $10^{-8} \mathrm{M}$ dexamethasone.

MSC alkaline phosphatase (ALP) activity following osteogenic induction with PNPP. Samples of high glucose DMEM supplemented with $1 \%$ FBS (low serum) were collected following culture with MSCs in plates for $48 \mathrm{~h}$, while the osteoinductive culture medium was added to the induction group. Osteoinductive drugs were added to the OBM and PNPP at final concentrations of $5 \times 10^{-8}, 1 \times 10^{-7}, 5 \times 10^{-7}, 1 \times 10^{-6}$ and $2.5 \times 10^{-6} \mathrm{M}$ Sal $\mathrm{B}$ and at $2 \times 10^{-6} \mathrm{M}$ DSU. An additional Sal B group was incubated without the PNPP bone-inducing agent, with a final concentration of Sal B of $5 \times 10^{-7} \mathrm{M}$. After 3, 5 and 7 days of osteogenic culture, the ALP content of the cells was assessed.

The experiment was conducted using nine groups in order to determine the effects of Sal B on the osteogenic differentiation of MSCs via regulation of the NO pathway. The groups included: A negative control group; osteogenic induction control group; nitric oxide inhibitor L-NAME group; Sal B group; DSU group; estradiol $\left(\mathrm{E}_{2}\right)$ group; L-NAME + DSU group; L-NAME + Sal B group; and a L-NAME + $\mathrm{E}_{2}$ group. The final concentration of L-NAME was $5 \times 10^{-7} \mathrm{M}$, of DSU was $2 \times 10^{-6} \mathrm{M}$, of Sal B was $5 \times 10^{-7} \mathrm{M}$ and of $\mathrm{E}_{2}$ was $10^{-8} \mathrm{M}$. On days 5 and 7, ALP activity was measured. Cultured cells were rinsed with PBS three times and $150 \mu$ l of substrate buffer (6.7 mM disodium p-nitrophenylphosphate hexahydrate, $25 \mathrm{mM}$ diethanolamine and $1 \mathrm{mM} \mathrm{MgCl}_{2}$ ) was subsequently added. Following incubation of the mixtures at $37^{\circ} \mathrm{C}$ for $30 \mathrm{~min}, 100 \mu \mathrm{l}$ of sodium hydroxide $(0.1 \mathrm{M})$ was added to stop each reaction. Subsequently, the optical density of each mixture was determined using a microplate reader at $405 \mathrm{~nm}$.

OCN in the conditioned MSC media by radioimmunoassay. High glucose DMEM supplemented with 10\% FBS was applied to the cells following culture in plates for $24 \mathrm{~h}$. Cells were cultured for a total of 22 days. Vitamin $\mathrm{D}_{3}\left(10^{-7} \mathrm{M}\right)$ was added to each group on day 18 . During the last $24 \mathrm{~h}$ of incubation, the culture medium was changed to serum-free DMEM. Before taking measurements, $100 \mu \mathrm{l}$ of labeled antigen and then $100 \mu \mathrm{l}$ of antibody were added to the conditioned media samples, which were incubated at $4^{\circ} \mathrm{C}$ for $18 \mathrm{~h}$. Following this, $1,000 \mu \mathrm{l}$ of the secondary antibody was added and the samples were centrifuged at $4000 \mathrm{x} \mathrm{g}$ at $4^{\circ} \mathrm{C}$ for $20 \mathrm{~min}$. The radioactivity of each sample was determined on a scintillation counter.

NO content of the conditioned MSC media after osteogenic induction using the nitrate reductase method. High glucose DMEM supplemented with $10 \%$ FBS was added to the cells following culture in plates for $24 \mathrm{~h}$, with control fluid, osteogenic induction agents. The cells were stimulated by 
Table I. Primer sequences used for reverse transcription-polymerase chain reaction.

\begin{tabular}{llll}
\hline Gene & Direction & Primer sequence & Product length (bp) \\
\hline$\beta$-actin & Forward & 5'-AACCCTAAGGCCAACCGTGAAAAG-3' & 240 \\
& Reverse & 5'-TCATGAGGTAGTCTGTCAGGT-3' & 578 \\
OPG & Forward & 5'-TCCTGGCACCTACCTAAAACAGCA-3' & 140 \\
RANKL & Reverse & 5'-CTACACTCTCTGCATTCACTTTGG-3' & \\
& Forward & 5'-TCCCAAGTTCGCATAACCTGA-3' & \\
& Reverse & 5'-GTTGGACACCTGGACGCTAATT-3' & \\
\hline
\end{tabular}

OPG, osteoprotegerin; RANKL, receptor activator of nuclear factor $\kappa$-B ligand.

osteogenic induction medium (OIM) composed of high glucose DMEM supplemented with $50 \mu \mathrm{g} / \mathrm{ml}$ L-ascorbic acid, $10^{-2} \mathrm{M} \beta$-glycerophosphate and $10^{-8} \mathrm{M}$ dexamethasone and the different drugs added to make the nine groups described above. On day 2 and 3 of culture, NO content of the conditioned media samples was measured.

RT-PCR analysis of osteoprotegerin (OPG) and nuclear factor- $\kappa B$ ligand (RANKL) gene expression levels by MSCs following osteogenic induction. High glucose DMEM supplemented with $1 \%$ FBS was added to the MSCs following culture in plates for $48 \mathrm{~h}$, and the bone induction agent (PNPP) was added to the induction group. Drugs in various concentrations were added to the cells to create the nine experimental groups as described. Total RNA was extracted from the cells in each group after 7 days of culture and purified using a TRIzol kit (Invitrogen; Thermo Fisher Scientific, Inc., Waltham, MA, USA), according to the manufacturer's instructions. Total RNA $(0.5 \mu \mathrm{g})$ was subjected to RT-PCR analysis using the 9600 GeneAmp PCR system (PerkinElmer Inc.) with PCR reagents from Invitrogen (Thermo Fisher Scientific, Inc.) and the primers listed in Table I. In the reaction for OPG, the RT step was performed at $50^{\circ} \mathrm{C}$ for $30 \mathrm{~min}$. Total RNA was extracted from cultured cells with RNeasyMini Kit (Qiagen, Inc., Valencia, CA, USA) and first-strand cDNA was synthesized using M-MLV reverse transcriptase (Promega Corporation, Madison, WI, USA) according to the manufacturer's protocol. Real-Time PCR was performed using the Step One Plus Real-Time PCR System (Applied Biosystems; Thermo Fisher Scientific, Inc.). The reaction conditions consisted of $15 \mu \mathrm{l}$ reaction volumes with diluted cDNA template $3 \mu 1,7.5 \mu 1$ SYBR-Green Master Mix (2x), 3.9 1 PCR-Grade water and $0.3 \mu \mathrm{l}$ of each primer $(10 \mu \mathrm{M})$. PCR amplification conditions were as follows: Denaturation at $94^{\circ} \mathrm{C}$ for $2 \mathrm{~min}$; followed by 35 cycles of $94^{\circ} \mathrm{C}$ for $30 \mathrm{sec}, 53^{\circ} \mathrm{C}$ for $30 \mathrm{sec}$ and $70^{\circ} \mathrm{C}$ for $45 \mathrm{sec}$; and a $72^{\circ} \mathrm{C}$ extension for $8 \mathrm{~min}$. In the reaction for RANKL, the RT step was performed at $50^{\circ} \mathrm{C}$ for $30 \mathrm{~min}$. PCR amplification conditions were as follows: Denaturation at $94^{\circ} \mathrm{C}$ for $2 \mathrm{~min}$; followed by 35 cycles of $94^{\circ} \mathrm{C}$ for $30 \mathrm{sec}, 60^{\circ} \mathrm{C}$ for $45 \mathrm{sec}$ and $70^{\circ} \mathrm{C}$ for $60 \mathrm{sec}$; and a $72^{\circ} \mathrm{C}$ extension for $8 \mathrm{~min}$. For the blank control, the RNA sample was substituted with $0.5 \mu \mathrm{l}$ of deionized water. The PCR products were subjected to $2 \%$ agarose gel electrophoresis, ethidium bromide staining and analysis with a gel imaging system. $\beta$-actin was used as an internal control reference.
Statistical analysis. Data were presented as mean \pm standard deviation. The statistical differences among groups were evaluated using one-way analysis of variance. $\mathrm{P}<0.05$ was considered to represent statistically significant differences.

\section{Results}

Morphology of rat MSCs following osteogenic induction. The cultured primary MSCs presented a variety of cell morphologies, with two types of cells appearing most frequently. One was a fibroblast-like cell with a fusiform or triangular shape. The other was a pancake-shaped epithelioid cell with an appearance similar to that of epithelial cells (Fig. 1). Over time in culture, the MSCs first formed small isolated colonies, and then the colonies enlarged until they merged together. After 14 days, the cells were passaged for the first time, and the fusiform, triangular and polygonal cells were trypsinized, collected and seeded into fresh culture flasks. The epithelioid cells that remained adhered to the wall of the flasks were disposed of in order to help purify the cell population. After 2-3 passages, the cells in the flask were a homogeneous population of fibroblast-like cells. The majority of the cells displayed a parallel or swirl-like growth pattern (Fig. 1). Following induction of osteogenesis, the passage three cells lost the original fibroblast-like morphology and assumed triangular or polygonal shapes (Fig. 1). Following 21 days in culture, the appearance of nodules was observed.

Effect of Sal B on ALP activity in MSCs treated with osteogenic induction agent. ALP activities of the MSCs in all groups were measured on days 3,5, and 7. Compared with the control group, Sal B at a concentration of $5 \times 10^{-7} \mathrm{M}$ significantly enhanced the secretion of ALP on day $3(\mathrm{P}<0.01$; Table II). When osteogenic induction agent was added, Sal B markedly increased the ALP activity; compared with the osteogenic induction group, the ALP activity was significantly increased at Sal B concentrations of $5 \times 10^{-8} \mathrm{M}, 5 \times 10^{-7} \mathrm{M}$ and $1 \times 10^{-6} \mathrm{M}$ (all $\mathrm{P}<0.01$ ). Additionally, DSU significantly increased the ALP activity of the cells at days 3,5 and 7 compared with the control $(\mathrm{P}<0.01)$ and osteogenic induction group (day 3 and 7 , $\mathrm{P}<0.01$; day 5, $\mathrm{P}<0.05$; Table II).

Effects of Sal B and DSU on the OCN content in media conditioned by MSCs. MSCs cultured for 22 days secreted a small amount of OCN. Even without the osteogenic induction 
Table II. Effects of Sal B and DSU on alkaline phosphatase activity in mesenchymal stem cells.

\begin{tabular}{|c|c|c|c|}
\hline Group & Day 3 & Day 5 & Day 7 \\
\hline Control & $0.252 \pm 0.033$ & $0.406 \pm 0.053$ & $0.442 \pm 0.039$ \\
\hline Sal B $5 \times 10^{-7} \mathrm{~mol} / \mathrm{l}$ (not OB-in) & $0.408 \pm 0.075^{\mathrm{a}, \mathrm{b}}$ & $0.436 \pm 0.025^{\mathrm{b}, \mathrm{c}}$ & $0.569 \pm 0.071^{\mathrm{b}}$ \\
\hline Osteogenic induction & $0.472 \pm 0.090^{\mathrm{a}, \mathrm{b}}$ & $0.707 \pm 0.030^{\mathrm{a}}$ & $0.648 \pm 0.072^{\mathrm{a}, \mathrm{b}}$ \\
\hline Sal B $5 \times 10^{-8} \mathrm{~mol} / \mathrm{l}(\mathrm{OB}-\mathrm{in})$ & $0.609 \pm 0.088^{\mathrm{a}, \mathrm{c}}$ & $0.794 \pm 0.095^{\mathrm{a}, \mathrm{b}, \mathrm{d}}$ & $0.873 \pm 0.148^{\mathrm{a}, \mathrm{c}}$ \\
\hline Sal B $10^{-7} \mathrm{~mol} / \mathrm{l}(\mathrm{OB}-\mathrm{in})$ & $0.519 \pm 0.047^{\mathrm{a}, \mathrm{b}}$ & $0.752 \pm 0.054^{\mathrm{a}, \mathrm{b}}$ & $0.794 \pm 0.096^{\mathrm{a}}$ \\
\hline Sal B $5 \times 10^{-7} \mathrm{~mol} / \mathrm{l}$ (OB-in) & $0.582 \pm 0.052^{\mathrm{a}, \mathrm{c}}$ & $0.724 \pm 0.035^{\mathrm{a}, \mathrm{d}}$ & $0.801 \pm 0.154^{\mathrm{a}, \mathrm{d}}$ \\
\hline Sal B $10^{-6} \mathrm{~mol} / \mathrm{l}$ (OB-in) & $0.611 \pm 0.049^{\mathrm{a}, \mathrm{c}}$ & $0.760 \pm 0.082^{\mathrm{a}, \mathrm{b}, \mathrm{d}}$ & $0.849 \pm 0.190^{\mathrm{a}, \mathrm{c}}$ \\
\hline Sal B $2.5 \times 10^{-6} \mathrm{~mol} / \mathrm{l}(\mathrm{OB}-\mathrm{in})$ & $0.619 \pm 0.047^{\mathrm{a}, \mathrm{c}}$ & $0.667 \pm 0.061^{\mathrm{a}}$ & $0.667 \pm 0.132^{\mathrm{a}, \mathrm{b}}$ \\
\hline DSU $2 \times 10^{-6} \mathrm{~mol} / \mathrm{l}$ (OB-in) & $0.654 \pm 0.092^{\mathrm{a}, \mathrm{c}}$ & $0.791 \pm 0.082^{\mathrm{a}, \mathrm{d}}$ & $0.887 \pm 0.163^{\mathrm{a}, \mathrm{c}}$ \\
\hline
\end{tabular}

Data are presented as the mean \pm standard deviation $(\mathrm{n}=6)$. ${ }^{\mathrm{a}} \mathrm{P}<0.01$ vs. the control group; ${ }^{\mathrm{b}} \mathrm{P}<0.01 \mathrm{vs}$. the $\mathrm{DSU}$ group; ${ }^{\mathrm{c}} \mathrm{P}<0.01$ and ${ }^{\mathrm{d}} \mathrm{P}<0.05$ vs. the osteogenic induction group. Sal B, salvianolic acid B; DSU, danshensu; OB-in, osteogenic-induced.
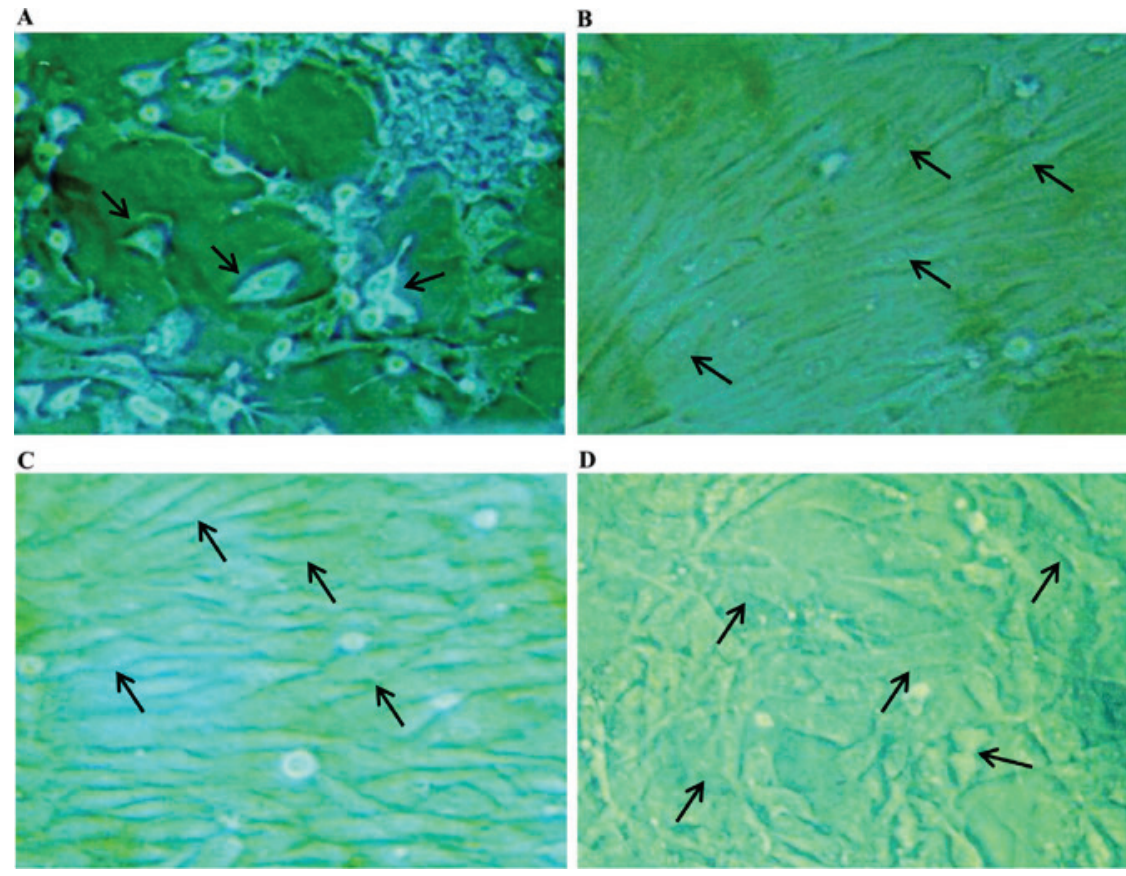

D

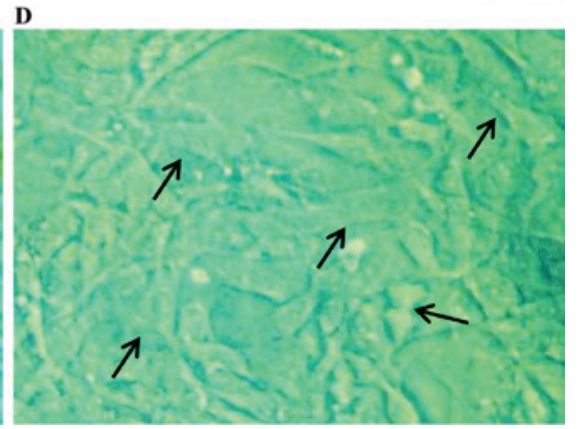

Figure 1. Rat mesenchymal stem cell morphology during (A) primary in vitro culture for 4 days, (B) passage two of in vitro culture after 3 days, (C) passage three of in vitro culture after 4 days and (D) after osteogenic induction in vitro for 7 days (alkaline phosphatase staining; magnification, $\mathrm{x} 200$ ).

agent, Sal B increased the content of OCN, with the largest, significant increase demonstrated at a drug concentration of $5 \times 10^{-7} \mathrm{M}(\mathrm{P}<0.05)$ compared with the control (Fig. 2). With the osteogenic induction agent, Sal B significantly increased the content of OCN at a Sal C concentration of $0.1(\mathrm{P}<0.05)$ and $0.5 \mu \mathrm{mol} / 1(\mathrm{P}<0.01)$ compared with the cells cultured without the osteogenic induction agent. DSU significantly increased the OCN content compared with the control $(\mathrm{P}<0.01)$ and increased $\mathrm{OCN}$ content to a greater extent than the increase observed with Sal B (Fig. 2).

Effects of Sal B on OPG and RANKL expression levels. Following osteogenic induction of MCSs, the expression levels of OPG significantly increased compared with the control (P<0.05; Fig. 3). Sal B at concentrations of 0.5 and $2.5 \mu \mathrm{M}$ and DSU at a concentration of $2 \mu \mathrm{M}$ significantly increased the
OPG expression levels in conditions with osteogenic induction compared with the control group.

RANKL expression levels significantly increased after osteogenic induction of the MSCs compared with the control group ( $\mathrm{P}<0.05$; Fig. 4). Sal B at concentrations of $0.05,0.5$ and $2.5 \mu \mathrm{M}$ and DSU at a concentration of $2 \mu \mathrm{M}$ significantly decreased the RANKL expression under conditions of osteogenic induction compared with the osteogenic induction group $(\mathrm{P}<0.05$; Fig. 4). Furthermore, Sal B at concentrations of 0.5 and $2.5 \mu \mathrm{M}$ and DSU at a concentration of $2 \mu \mathrm{M}$ significantly increased the OPG/RANKL ratio compared with the control ( $\mathrm{P}<0.05$; Fig. 5).

Effect of Sal B on NO content in the conditioned media of MSCs following osteogenic induction. Compared with the control group, the content of NO was significantly increased in the osteogenic induction group $(\mathrm{P}<0.05$; Table III). NO 


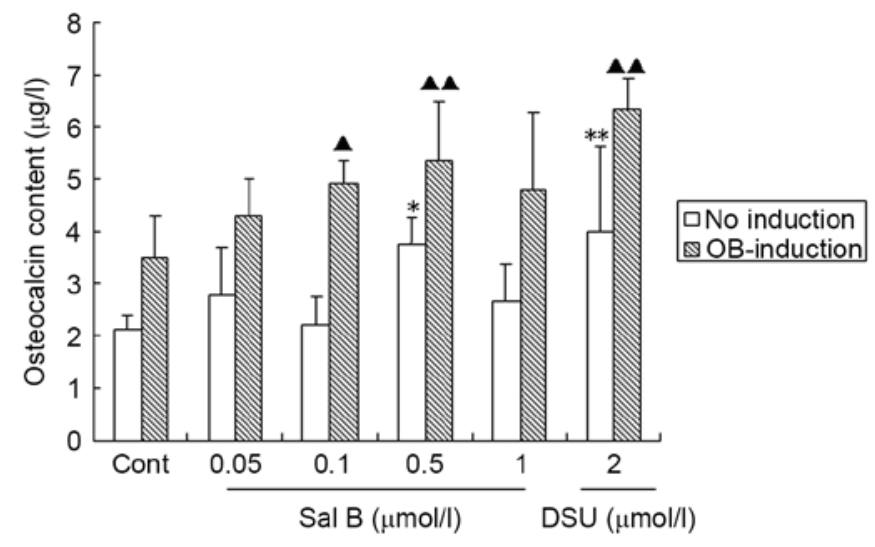

Figure 2. Effect of Sal B and DSU on osteocalcin content in the conditioned media from mesenchymal stem cells at day 22. Data are presented as the mean + standard deviation $(\mathrm{n}=6){ }^{*} \mathrm{P}<0.05$ and ${ }^{* *} \mathrm{P}<0.01$ vs. the Cont group; ${ }^{\Delta} \mathrm{P}<0.05$ and ${ }^{\boldsymbol{\Delta}} \mathrm{P}<0.01$ vs. the OB-induction group. Sal $\mathrm{B}$, salvianolic acid $\mathrm{B}$; DSU, danshensu; Cont, control; OB-induction, osteogenic induction group.

$\mathbf{A}$

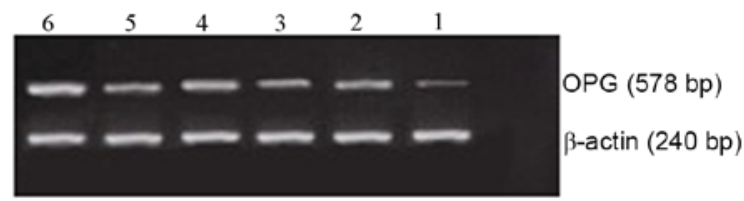

B

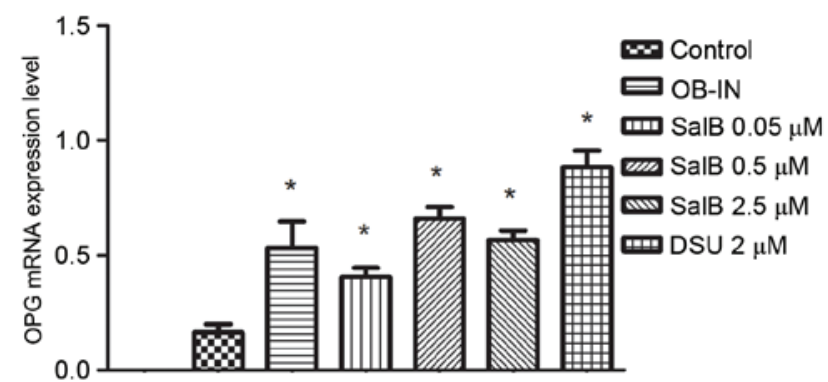

Figure 3. (A) Reverse transcription-polymerase chain reaction examination of OPG mRNA expression levels by mesenchymal stem cells cultured in (1) control media, (2) osteogenic induction media, (3) $0.05 \mu \mathrm{M} \mathrm{Sal} \mathrm{B}$ (4) $0.5 \mu \mathrm{M} \mathrm{Sal} \mathrm{B,(5)} 2.5 \mu \mathrm{M} \mathrm{Sal} \mathrm{B}$ and (6) $2 \mu \mathrm{M}$ danshensu. (B) Quantification of the effects of Sal B on the mRNA expression level of OPG in mesenchymal stem cells. Data are presented as the mean \pm standard deviation. $\mathrm{P}<0.05$ vs. control. Sal B, salvianolic acid B; OPG, osteoprotegerin; OB-IN, osteogenic induction; DSU, danshensu.

synthase inhibitor (L-NAME) at a concentration of $5 \times 10^{-3} \mathrm{M}$ significantly decreased the NO content compared with the osteogenic induction group on day $2(\mathrm{P}<0.05)$ and compared to the control and osteogenic group on day 3 (both $\mathrm{P}<0.01$; Table III). Sal B, DSU and $\mathrm{E}_{2}$ all significantly increased the NO content compared with the control and osteogenic induction groups $(\mathrm{P}<0.01)$, particularly at day 3 , significantly reversing the inhibitory effect of L-NAME on NO production $(\mathrm{P}<0.01$; Table III).

Effect of Sal B on ALP content after suppression by L-NAME. Compared with the osteogenic induction group, L-NAME significantly decreased the content of ALP $(\mathrm{P}<0.01)$ on days 5 and 7, whereas both Sal $\mathrm{B}$ and $\mathrm{E}_{2}$ significantly increased the
A

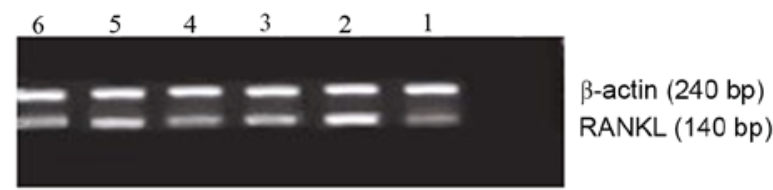

B

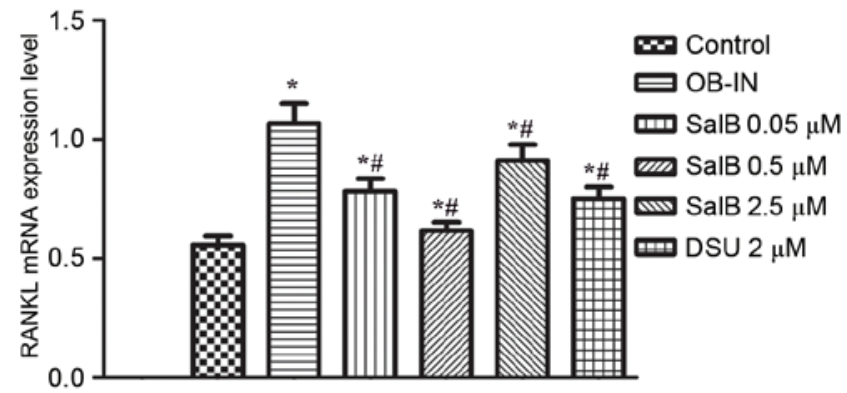

Figure 4. (A) Reverse transcription-polymerase chain reaction examination of RANKL mRNA expression levels by mesenchymal stem cells cultured in (1) control media,(2) osteogenic induction media,(3) $0.05 \mu \mathrm{M} \mathrm{Sal} \mathrm{B,} \mathrm{(4)} 0.5 \mu \mathrm{M}$ Sal B, (5) $2.5 \mu \mathrm{M}$ Sal B and (6) $2 \mu \mathrm{M}$ danshensu. (B) Quantification of the effects of Sal B on the mRNA expression levels of RANKL in mesenchymal stem cells. Data are presented as the mean \pm standard deviation. ${ }^{*} \mathrm{P}<0.05$ vs. the control, "P<0.05 vs. the OB-IN group. Sal B, salvianolic acid B; RANKL, receptor activator of nuclear factor- $\mathrm{kB}$ ligand; OB-IN, osteogenic induction; DSU, danshensu.

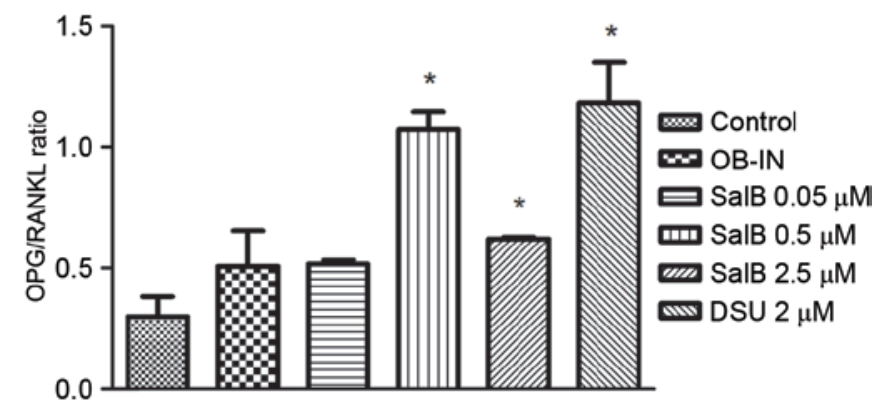

Figure 5. Effect of Sal B on the mRNA expression level ratio of OPG and RANKL by mesenchymal stem cells. Data are presented as the mean \pm standard deviation. "P<0.05 vs. control. Sal B, salvianolic acid B; OPG, osteoprotegerin; RANKL, receptor activator of nuclear factor- $\mathrm{\kappa B}$ ligand; OB-IN, osteogenic induction; DSU, danshensu.

content of ALP $(\mathrm{P}<0.01)$ on days 5 and 7 , and DSU significantly increased the content of ALP on day $7(\mathrm{P}<0.05)$. Compared with the L-NAME group $\left(5 \times 10^{-3} \mathrm{M}\right)$, the ALP content was significantly increased in the L-NAME + Sal B group on day 7 $(\mathrm{P}<0.01)$, as well as in the L-NAME + DSU group on days 5 and $7(\mathrm{P}<0.05$; Table IV).

Effect of Sal B on OCN content after suppression by L-NAME. Compared with the osteogenic induction group, L-NAME $\left(5 \times 10^{-3} \mathrm{M}\right)$ significantly decreased OCN content of the conditioned media $(\mathrm{P}<0.01)$. However, Sal B and DSU significantly increased OCN content compared with the osteogenic induction group (both $\mathrm{P}<0.01$ ), and $\mathrm{OCN}$ content was also increased in the $\mathrm{E}_{2}$ group (Table V). Compared with the L-NAME group, OCN content in the L-NAME + DSU and L-NAME + Sal B groups was significantly increased (both $\mathrm{P}<0.01$ ), and no 
Table III. Effects of various drugs on nitric oxide secretion by mesenchymal stem cells in osteoblast medium.

\begin{tabular}{|c|c|c|}
\hline Group & Day 2 & Day 3 \\
\hline Control & $110.185 \pm 4.839$ & $105.741 \pm 4.182$ \\
\hline Induction control & $122.778 \pm 3.123^{\mathrm{a}}$ & $114.444 \pm 5.305^{\mathrm{a}}$ \\
\hline $\mathrm{E} 210^{-8} \mathrm{~mol} / \mathrm{l}$ & $136.296 \pm 5.823^{\mathrm{b}-\mathrm{d}}$ & $130.000 \pm 9.788^{\mathrm{b}, \mathrm{d}, \mathrm{e}}$ \\
\hline Sal B $5 \times 10^{-7} \mathrm{~mol} / \mathrm{l}$ & $131.482 \pm 9.498^{\mathrm{d}}$ & $127.407 \pm 7.971^{\mathrm{b}, \mathrm{d}, \mathrm{e}}$ \\
\hline DSU $2 \times 10^{-6} \mathrm{~mol} / 1$ & $129.259 \pm 4.077^{\mathrm{b}, \mathrm{d}}$ & $131.852 \pm 7.687^{\mathrm{b}, \mathrm{d}, \mathrm{e}}$ \\
\hline L-NAME $5 \times 10^{-3} \mathrm{~mol} / 1$ & $84.444 \pm 12.492^{c}$ & $87.407 \pm 5.907^{\mathrm{b}, \mathrm{e}}$ \\
\hline L-NAME $+\mathrm{E}_{2}$ & $99.444 \pm 9.129^{c}$ & $110.185 \pm 5.040^{\mathrm{d}}$ \\
\hline L-NAME + Sal B & $101.852 \pm 4.852^{\mathrm{e}}$ & $113.333 \pm 7.166^{\mathrm{d}}$ \\
\hline L-NAME + DSU & $101.111 \pm 10.447$ & $110.556 \pm 9.706^{\mathrm{d}}$ \\
\hline
\end{tabular}

Data are presented as the mean \pm standard deviation $(\mathrm{n}=6)$. ${ }^{\mathrm{a}} \mathrm{P}<0.05$ and ${ }^{b} \mathrm{P}<0.01$ vs. the control group; ${ }^{\mathrm{c}} \mathrm{P}<0.05$ and ${ }^{\mathrm{e}} \mathrm{P}<0.01$ vs. the osteogenic induction group; ${ }^{\mathrm{d}} \mathrm{P}<0.01 \mathrm{vs}$. the L-NAME group. $\mathrm{E}_{2}$, prostaglandin $\mathrm{E}_{2}$; Sal B, salvianolic acid B; DSU, danshensu; L-NAME, $\mathrm{N}$-nitro L-arginine methyl ester.

Table IV. Effects of various drugs on the alkaline phosphatase activity of mesenchymal stem cells in osteoblast medium.

\begin{tabular}{lll}
\hline Group & \multicolumn{1}{c}{ Day 5} & \multicolumn{1}{c}{ Day 7} \\
\hline Control & $0.229 \pm 0.054$ & $0.220 \pm 0.017$ \\
Induction control & $0.390 \pm 0.027^{\mathrm{a}}$ & $0.361 \pm 0.042^{\mathrm{a}}$ \\
$\mathrm{E}_{2} 10^{-8} \mathrm{~mol} / \mathrm{l}$ & $0.451 \pm 0.035^{\mathrm{a}-\mathrm{c}}$ & $0.412 \pm 0.023^{\mathrm{a}, \mathrm{c}, \mathrm{d}}$ \\
Sal B5X10 $^{-7} \mathrm{~mol} / 1$ & $0.460 \pm 0.043^{\mathrm{a}-\mathrm{c}}$ & $0.420 \pm 0.045^{\mathrm{a}-\mathrm{c}}$ \\
DSU $2 \times 10^{-6} \mathrm{~mol} / \mathrm{l}$ & $0.422 \pm 0.047^{\mathrm{a}, \mathrm{c}}$ & $0.406 \pm 0.034^{\mathrm{a}, \mathrm{c}, \mathrm{d}}$ \\
L-NAME $5 \times 10^{-3} \mathrm{~mol} / 1$ & $0.273 \pm 0.037^{\mathrm{a}, \mathrm{b}}$ & $0.238 \pm 0.030^{\mathrm{b}, \mathrm{e}}$ \\
L-NAME $+\mathrm{E}_{2}$ & $0.360 \pm 0.042^{\mathrm{b}}$ & $0.323 \pm 0.042^{\mathrm{b}, \mathrm{c}, \mathrm{e}}$ \\
L-NAME + Sal B & $0.315 \pm 0.037^{\mathrm{a}, \mathrm{b}}$ & $0.290 \pm 0.036^{\mathrm{a}-\mathrm{c}}$ \\
L-NAME + DSU & $0.326 \pm 0.036^{\mathrm{a}, \mathrm{b}, \mathrm{f}}$ & $0.293 \pm 0.037^{\mathrm{a}-\mathrm{c}}$ \\
\hline
\end{tabular}

Data are presented as the mean \pm standard deviation of optical densities $(\mathrm{n}=6)$. ${ }^{\mathrm{a}} \mathrm{P}<0.01$ and ${ }^{\mathrm{b}} \mathrm{P}<0.05$ vs. the control group; ${ }^{\mathrm{C}} \mathrm{P}<0.01$ and ${ }^{d} \mathrm{P}<0.05$ vs. the osteogenic induction group; ${ }^{e} \mathrm{P}<0.01$ and ${ }^{\mathrm{f}} \mathrm{P}<0.05$ vs. the L-NAME group. $\mathrm{E}_{2}$, prostaglandin $\mathrm{E}_{2}$; Sal $\mathrm{B}$, salvianolic acid B; DSU, danshensu; L-NAME, N-nitro L-arginine methyl ester.

significant effect was demonstrated in the L-NAME $+\mathrm{E}_{2}$ group (Table V). These results suggest that Sal B and DSU may reverse the inhibitory effect of L-NAME on OCN secretion.

Effect of Sal B on the mRNA expression levels of OPG and RANKL after suppression by L-NAME. As demonstrated in Fig. 6 osteogenic induction increased OPG mRNA expression levels compared with the control $(\mathrm{P}<0.05)$. However, the expression levels of OPG mRNA decreased in the L-NAME group. Sal B, DSU and $\mathrm{E}_{2}$ significantly increased OPG mRNA expression levels compared with the osteogenic induction $(\mathrm{P}<0.05$; Fig. 6). In contrast with L-NAME alone, L-NAME + DSU, $\mathrm{L}-\mathrm{NAME}+\mathrm{Sal} \mathrm{B}$ and L-NAME $+\mathrm{E}_{2}$ all significantly increased the expression of OPG mRNA $(\mathrm{P}<0.05$; Fig. 6$)$.
Table V. Effects of various drugs on the osteocalcin content of conditioned osteoblast medium from mesenchymal stem cells.

\begin{tabular}{lc}
\hline Group & Osteocalcin $(\mu \mathrm{g} / \mathrm{l})$ \\
\hline Induction control & $2.876 \pm 0.410$ \\
$\mathrm{E}_{2} 10^{-8} \mathrm{~mol} / \mathrm{l}$ & $4.767 \pm 0.678^{\mathrm{a}}$ \\
$\mathrm{Sal} \mathrm{B} 5 \times 10^{-7} \mathrm{~mol} / \mathrm{l}$ & $4.450 \pm 0.768^{\mathrm{b}}$ \\
DSU $2 \times 10^{-6} \mathrm{~mol} / \mathrm{l}$ & $4.428 \pm 1.058^{\mathrm{b}}$ \\
$\mathrm{L}-\mathrm{NAME} 5 \times 10^{-3} \mathrm{~mol} / \mathrm{l}$ & $1.737 \pm 0.816^{\mathrm{b}}$ \\
L-NAME $+\mathrm{E}_{2}$ & $2.555 \pm 0.478$ \\
L-NAME + Sal B & $3.921 \pm 0.539^{\mathrm{c}, \mathrm{d}}$ \\
L-NAME + DSU & $3.932 \pm 0.343^{\mathrm{b}, \mathrm{d}}$
\end{tabular}

Data are presented as the mean \pm standard deviation $(\mathrm{n}=6)$. ${ }^{\mathrm{a}} \mathrm{P}<0.05$ and ${ }^{b} \mathrm{P}<0.05$ vs. the L-NAME group; ${ }^{c} \mathrm{P}<0.01$ and ${ }^{\mathrm{d}} \mathrm{P}<0.05$ vs. the osteogenic induction group. $\mathrm{E}_{2}$, prostaglandin $\mathrm{E}_{2}$; Sal $\mathrm{B}$, salvianolic acid B; DSU, danshensu; L-NAME, N-nitro L-arginine methyl ester.

As demonstrated in Fig. 7, the mRNA expression level of RANKL was significantly increased in the osteogenic induction groups compared with the control $(\mathrm{P}<0.05)$. Sal B, DSU and $E_{2}$ significantly decreased the expression of RANKL, L-NAME and increased the expression of RANKL, compared with the osteogenic induction $(\mathrm{P}<0.05$; Fig. 7). Compared with L-NAME alone, L-NAME + DSU, L-NAME + Sal B and $\mathrm{L}-\mathrm{NAME}+\mathrm{E}_{2}$ all significantly decreased the expression of RANKL ( $\mathrm{P}<0.05$; Fig. 7).

As demonstrated in Fig. 8, the OPG/RANKL ratio was not significantly altered in the osteogenic induction group compared with the control group. L-NAME significantly decreased the OPG/RANKL ratio compared with the osteogenic induction control $(\mathrm{P}<0.05)$, whereas Sal $\mathrm{B}$, DSU and $\mathrm{E}_{2}$ increased the OPG/RANKL ratio $(\mathrm{P}<0.05)$. Compared with L-NAME alone, L-NAME + DSU, L-NAME + Sal B and $\mathrm{L}-\mathrm{NAME}+\mathrm{E}_{2}$ significantly increased the OPG/RANKL ratio $(\mathrm{P}<0.05$; Fig. 8).

\section{Discussion}

MSC differentiation has a key role in the incidence and development of osteoporosis. Drugs that regulate the differentiation of MSCs, particularly those that promote the osteogenic differentiation of MSCs, may be beneficial for the treatment of osteoporosis. The osteogenic processes that MSCs undergo during in vitro culture include the transition phase, cellular proliferative stage, cell aggregate secretory period and the extracellular matrix calcification period. One indicator of the cell aggregate secretory period is the distinct increase in ALP level (6). Following the cell aggregate secretory period is the extracellular matrix calcification period, during which the expression of OCN reaches its peak (7). The results of the present study demonstrate that Sal B is able to increase the activity of ALP produced by MSCs following osteogenic induction, as well as increase the level of OCN. These results were consistent with a previous study that investigated the effects of Sal B on osteoblasts, which found that Sal B exerted its largest effects during the middle and later periods 
A

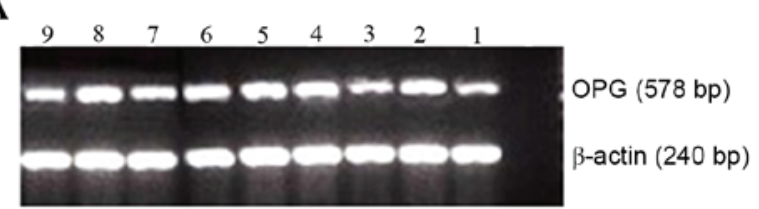

B

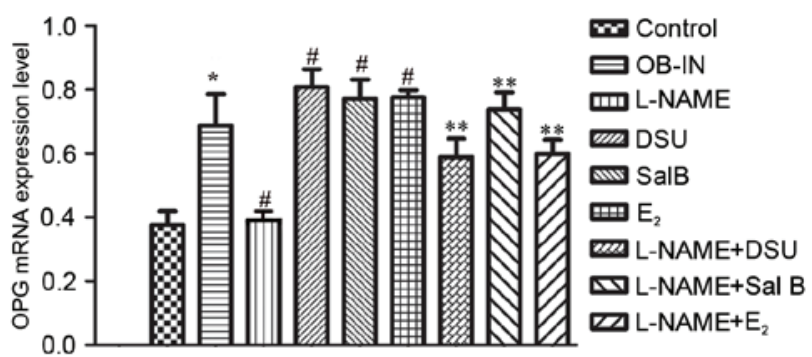

Figure 6. (A) Reverse transcription-polymerase chain reaction examination of OPG mRNA expression levels by mesenchymal stem cells cultured in (1) control media, (2) osteogenic induction media, (3) L-NAME, (4) DSU, (5) Sal B, (6) $\mathrm{E}_{2}$, (7) L-NAME+DSU, (8) L-NAME + Sal B and (9) L-NAME $+E_{2}$. (B) Quantification of the effects of several drugs on the mRNA expression level of OPG by mesenchymal stem cells cultured in osteogenic induction media. Data are presented as the mean \pm standard deviation. ${ }^{*} \mathrm{P}<0.05$ vs. control, ${ }^{\#} \mathrm{P}<0.05$ vs. OB-IN group, ${ }^{* *} \mathrm{P}<0.05$ vs. L-NAME group. OPG, osteoprotegerin; OB-IN, osteogenic induction; L-NAME, $\mathrm{N}$-nitro L-arginine methyl ester; DSU, danshensu; Sal B, salvianolic acid B; $\mathrm{E}_{2}$, prostaglandin $\mathrm{E}_{2}$

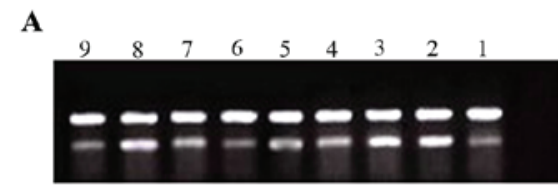

$\beta$-actin (240 bp) RANKL (140 bp)

B

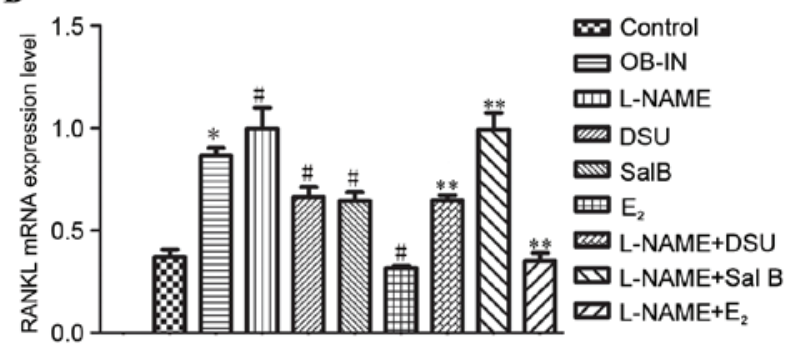

Figure 7. (A) Reverse transcription-polymerase chain reaction examination of RANKL mRNA expression levels by mesenchymal stem cells cultured in (1) control media, (2) osteogenic induction media, (3) L-NAME, (4) DSU, (5) Sal B, (6) $\mathrm{E}_{2}$, (7) L-NAME + DSU, (8) L-NAME + Sal B and (9) L-NAME $+E_{2}$. (B) Quantification of the effects of several drugs on the mRNA expression level of RANKL by mesenchymal stem cells in osteogenic induction media. Data are presented as the mean \pm standard deviation. ${ }^{*} \mathrm{P}<0.05$ vs. control, ${ }^{\#} \mathrm{P}<0.05$ vs. OB-IN group, ${ }^{* *} \mathrm{P}<0.05$ vs. L-NAME group. RANKL, receptor activator of nuclear factor- $\kappa \mathrm{B}$ ligand; OB-IN, osteogenic induction; L-NAME, N-nitro L-arginine methyl ester; DSU, danshensu; Sal B, salvianolic acid B; $\mathrm{E}_{2}$, prostaglandin $\mathrm{E}_{2}$.

of the bone formation process, when the MSCs differentiate towards osteoblasts (8). Sal B also promoted the differentiation of MSCs into osteoblasts and the differentiated functions of mature osteoblasts (8). Sal B has been reported to influence the expression of transforming growth factor (TGF)- $\beta 1$ and its receptor protein in rats with liver fibrosis induced by

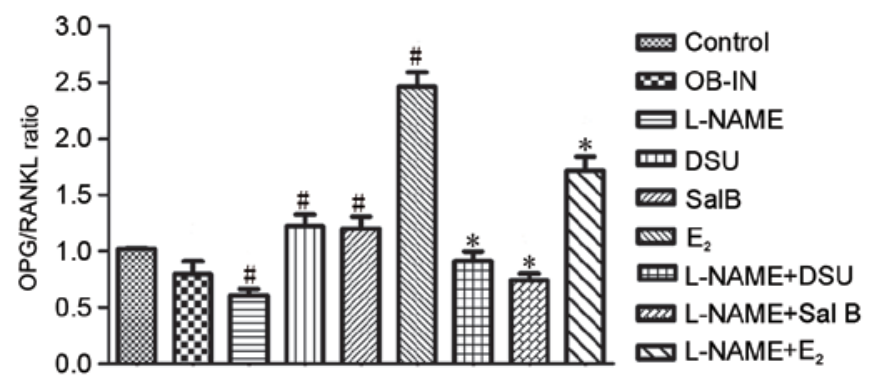

Figure 8. Effects of a number of different drugs on the mRNA expression level ratio of OPG and RANKL by mesenchymal stem cells in osteogenic induction media. Data are presented as the mean \pm standard deviation. ${ }^{\#} \mathrm{P}<0.05$ vs OB-IN group, ${ }^{*} \mathrm{P}<0.05$ vs. L-NAME group. OPG, osteoprotegerin; RANKL, receptor activator of nuclear factor- $\kappa \mathrm{B}$ ligand; OB-IN, osteogenic induction; L-NAME, N-nitro L-arginine methyl ester; DSU, danshensu; Sal B, salvianolic acid $\mathrm{B} ; \mathrm{E}_{2}$, prostaglandin $\mathrm{E}_{2}$.

dimethyl nitrosamine administration (9). TGF- $\beta 1$ and bone morphogenetic protein both belong to the TGF- $\beta$ superfamily. In combination with the receptor, which has serine/threonine kinase activity, molecules in this superfamily induce cytological effects through signaling pathways involved in the osteogenic differentiation of MSCs (10). TGF- $\beta 1$, a powerful factor that facilitates osteogenic differentiation, promotes the activity of ALP and stimulates the synthesis of type I collagen, osteonectin and osteopontin (11). These molecules may contribute to the regulation of TGF- $\beta 1$ by Sal B, which may strengthen the osteogenic differentiation of MSCs.

Bone metabolism includes both bone formation and resorption. Under normal conditions, total bone mass remains in balance due to an equilibrium between the quantity and activity of osteoblasts and osteoclasts (12). The OPG/RANKL pathway is required to maintain the bone mass in dynamic equilibrium and the OPG/RANKL concentration ratio is a decisive factor for the induction of osteoclast differentiation (13). Several cytokines and hormones, which regulate the behavior of osteoclasts in vivo, act mainly by influencing the secretion of OPG and RANKL (14). The results reported in the present study demonstrated that Sal B is able to increase the OPG/RANKL ratio during osteogenic differentiation by MSCs. One explanation for this result may be related to the mediating effect of TGF- $\beta 1$. TGF- $\beta 1$ is a multi-functional cytokine that is able to both promote the expression of OPG and inhibit the expression of RANKL (15). Another explanation may be that Sal B affects the level of glutamic acid. Several articles have reported that total salvianolic acid, containing Sal B, decreased the release of glutamic acid at certain concentrations (16). Osteoblasts and MSCs display glutamate receptors, and glutamic acid works through glutamate receptors to alter the activity of nitric oxide synthase (NOS), thereby regulating the osteogenic differentiation of MSCs (17). A study by Foreman et al (18) reported that L-glutamic acid inhibits calcium channels, decreasing the concentration of calcium ions within cells. $\mathrm{Ca}^{2+}$-calmodulin affects the activity of NOS, which also declines with the concentration of calcium; however, this effect disappears in the presence of glutamate receptor inhibitor (18). Alterations to the activity of NOS result in changes in the levels of NO. This may help to explain why Sal B altered the expression of OPG/RANKL in the present study. 
In addition, the ability of Sal B to reverse the suppressive effects of L-NAME was investigated in the present study to verify that Sal B works through the NO pathway. NO, an inorganic free radical gas is produced from L-arginine through the oxidation of guanidine nitrogen and is catalyzed by NOS. In a previous study it was demonstrated that NO and NOS have key roles in osteoporosis by participating in and promoting its pathophysiological processes (19). NO has an important role in the regulation of information transmission, both within individual cells and between neighboring cells, and thereby regulates the bone remodeling process (19). NO enhances cytokine-induced bone resorption that is closely related to the lack of estrogen in postmenopausal women with osteoporosis (20). NOS is predominantly present in bone tissue as inducible NOS (iNOS) and endothelial NOS (eNOS) (21). Osteoblasts and osteoclasts both secrete $\mathrm{NO}$, which has autocrine and paracrine effects and is involved in the regulation of osteoblasts and osteoclasts (22). NOS and NO display bidirectional regulation of osteoclast function (23). A basal concentration of NO is essential for maintaining the normal resorption activity of osteoclasts; however, when the concentration of NO increases above a certain threshold, it may significantly increase the resorption activity of osteoclasts by stimulating the activity of cyclic guanosine monophosphate to induce cytotoxicity (24). Under normal physiological conditions, eNOS has a major role in the regulation of bone formation and has an important role in the occurrence of osteoblast differentiation and maturation (25). The NO donor sodium nitroprusside is able to increase the OPG/RANKL ratio in MSCs, thereby promoting osteogenesis, while the NO donor nitroglycerin is able to mitigate glucocorticoid-induced bone loss in rats (26). Exogenous' arginine may increase the serum level of NO, indirectly increasing the bone mineral density of postmenopausal patients with osteoporosis (27); however, high concentrations of NO may inhibit the maturation, differentiation and function of osteoblasts.

As the experimental results of the present study demonstrated, non-induced MSCs secrete little NO, and NO secretion increases after osteogenic induction. L-NAME, an eNOS-specific inhibitor, is able to significantly decrease the level of NO secreted by MSCs after osteogenic induction. In the present study, the ALP activity and OCN content of the L-NAME group were significantly lower than those of the osteogenic induction control group. Sal B, DSU and $\mathrm{E}_{2}$ are able to stimulate the secretion of $\mathrm{NO}$ and reverse the inhibitory effects of L-NAME on NO synthesis, promoting osteogenic differentiation of MSCs. $\mathrm{E}_{2}$ not only promotes the secretion of NO, it also helps to regulate eNOS. The binding of estrogen and the estrogen receptor to osteoblasts activates eNOS through the mitogen activated protein kinase and phosphoinositide 3-kinase/protein kinase B pathways, which produces physiological levels of NO that regulate the activity of osteoblasts and osteoclasts (28). Estrogen is also able to increase eNOS gene expression levels and the in vitro activity of cultured human osteoblasts (29).

Furthermore, the results of the present study demonstrated that $\mathrm{E}_{2}$ promotes the secretion of $\mathrm{NO}$ by MSCs, possibly by influencing eNOS, as L-NAME is an eNOS-specific inhibitor. The results also indicated that the NO content in the L-NAME $+\mathrm{E}_{2}$ group was significantly lower than that in the $\mathrm{E}_{2}$ group. The L-NAME + Sal B and L-NAME + DSU groups also demonstrated similar effects. It is possible to speculate that Sal B and DSU promote the secretion of NO by MSCs by affecting eNOS. The low expression level of eNOS-dependent NO has been reported to be an important characteristic of the pathogenesis of glucocorticoid-induced osteoporosis (30). The effects of Sal B on NO may be beneficial for the treatment of glucocorticoid-induced osteoporosis. A previous study demonstrated that the NO concentration in patients with coronary heart disease was significantly higher after administration of the compound danshen, which helped to maintain myocardial perfusion (31). Magnesium lithospermate $\mathrm{B}$ has been demonstrated to reduce the endothelial cell damage caused by hypoxia and reoxygenation and increased endothelial NO release (32). Phenolic acids mainly consisting of Sal B have similar effects as angiotensin-converting enzyme-inhibitors (ACEIs) (33). ACEIs competitively inhibit the angiotensin-converting enzyme, thereby increasing NO production (34). These findings suggest that Sal B has a direct or indirect role in the promotion of NO secretion.

L-NAME suppresses the expression levels of OPG mRNA by MSCs under osteogenic induction, which increases the expression levels of RANKL mRNA, decreasing the OPG/RANKL ratio (35). Through the nuclear factor- $\kappa \mathrm{B}$ and interferon- $\beta$ signaling pathways, RANKL induces the expression of iNOS and the production of NO, which decreases the generation of RANKL-stimulated osteoclasts, acting as a type of autocrine feedback signal (36). Estradiol is able to increase the OPG/RANKL ratio (37). Sal B and estradiol exhibit the same effects on the expression of OPG and RANKL genes with or without L-NAME (38). It has been demonstrated that NO donors may increase the OPG expression in the bone tissue of ovariectomized mice (39). At appropriate concentrations, NO donors promote the proliferation of mouse MSCs and the protein expression levels of OPG, while high doses of NO donors inhibit the proliferation of MSCs and the synthesis of OPG (40). The promotion of OPG synthesis by NO donors was related to the activation of the tyrosine kinase and Runx2 genes in MSCs by NO (40). Furthermore, cyclic guanosine monophosphate was reported to not mediate this process (39). Sal B is similar to other $\mathrm{NO}$ donors in its promotion of $\mathrm{NO}$ secretion and elevation of NO levels, which may increase the OPG/RANKL expression ratio. First, Sal B promotes the secretion of NO. A study assessing cardiovascular disease (coronary heart disease and high blood pressure) and osteoporosis reported that the water-soluble ingredients of $S$. miltiorrhiza promote the secretion of NO (41). Second, the NO level is significantly correlated with the expression of OPG and RANKL (42). Previously, it has been demonstrated that NO is able to alter the bone resorption activity of osteoclasts and is involved in the occurrence and development of bone loss after menopause (42). Furthermore, NO donors are able to increase the OPG/RANKL ratio in MSCs. Third, L-NAME is able to decrease the OPG/RANKL ratio in cells under osteogenic induction; however, Sal B is able to reverse this effect. Fourth, estrogen is recognized as an anti-osteoporosis drug, and its anti-osteoporosis effects are related to NO $(43,44)$. In addition, estrogen achieves the regulation of osteoclasts through the NO pathway to alter the OPG/RANKL ratio, 
and estrogen stimulation is able to mediate the formation of osteoclasts and rapid bone loss after menopause (42). Therefore, it is possible to conclude that Sal B and DSU have similar roles in the regulation of bone absorption as estradiol; they increase the OPG/RANKL expression ratio via the NO pathway, which indirectly regulates osteoclasts.

In conclusion, Sal B promotes the osteogenic differentiation of MSCs in vitro. Furthermore, it is able to increase the OPG/RANKL mRNA expression level ratio during the osteogenic differentiation phases, an effect that may be mediated by the NO pathway.

\section{Acknowledgements}

The present study was supported by grants from: The National Natural Science Foundation of China (grant nos. 81273518 and 81373499); Guangdong Province Science and Technology Plan (grant nos. 2012B060300027 and 2012B031800225); and the Science and Technology Innovation Fund of Guangdong Medical College (grant no. STIF201104).

\section{References}

1. Cui L, Li T, Liu Y, Zhou L, Li P, Xu B, Huang L, Chen Y, Liu Y, Tian X, et al: Salvianolic acid B prevents bone loss inprednisone-treated rats through stimulation of osteogenesis and bone marrow angiogenesis. PLoS One 7: e34647, 2012.

2. He H,Shi M,Zeng X, Yang J,Li Y,Wu L and Li L: Cardioprotective effect of salvianolic acid B on large myocardial infarction mediated by reversing upregulation of leptin, endothelin pathways, and abnormal expression of SERCA2a, phospholamban in rats. J Ethnopharmacol 118: 35-45, 2008.

3. Yokozawa T, Lee TW, Oura H, Nonaka G and Nishioka I: Effect of magnesium lithospermate B in rats with sodiuminduced hypertension and renal failure. Nephron 60: 460-465, 1992

4. Kamata K, lizuka T Nagai M and Kasuya Y: Endotheliumdependent vasodilator effects of the extract from Salviae Mltiorrhizaera dix: A study on the identification of lithospermic acid B in the extracts. Cen Pharmacol 24: 977-981, 1993.

5. Majumdar MK, Thiede MA, Mosca JD, Moorman M and Gerson SL: Phenotypic and functional comparison of cultures of marrow derived mesenchymal stem cells (MSCs) and stromal cells. J Cell Physiol 176: 57-66, 1998.

6. Grandin HM, Gemperli AC and Dard M: Enamel matrix derivative: A review of cellular effects in vitro and a model of molecular arrangement and functioning. Tissue Eng Part B Rev 18: 181-202, 2012.

7. Lyu Y, Feng X, Zhao P, Wu Z, Xu H, Fang Y, Hou Y, Denney L, $\mathrm{Xu} \mathrm{Y}$ and Feng H: Fructus Ligustri Lucidi (FLL) ethanol extract increases bone mineral density and improves bone properties in growing female rats. J Bone Miner Metab 32: 616-626, 2014.

8. Cui L, Li T, Liu Y, Zhou L, Li P, Xu B, Huang L, Chen Y, Liu Y, Tian X, et al: Salvianolic acid B prevents bone loss in prednisone-treated rats through stimulation of osteogenesis and bone marrow angiogenesis. PLoS One 7: e34647, 2012.

9. Wang XN, Hu YY and Liu CH: The Influence on the livers of rats with hepatic fibrosis transforming growth factor 1 Induced by two dimethyl nitrosamine and receptor protein expression by Salvianolic acid B salt. Zhong Xi Yi Jie He Xue Bao 3: 286-289, 2005 (In Chinese).

10. Tan J, Lu J, Huang W, Dong Z, Kong C, Li L, Gao L, Guo J and Huang B: Genome-wide analysis of histone $\mathrm{H} 3$ lysine9 modifications in human mesenchymal stem cell osteogenic differentiation. PLoS One 4: e6792, 2009.

11. Xing Q, Qian Z, Kannan B, Tahtinen M and Zhao F: Osteogenic differentiation evaluation of an engineered extracellular matrix based tissue sheet for potential periosteum replacement. ACS Appl Mater Interfaces 7: 23239-23247, 2015.

12. Klika V, Pérez MA, García-Aznar JM, Maršík F and Doblaré M A coupled mechano-biochemical model for bone adaptation. J Math Biol 69: 1383-1429, 2014.
13. Kawahara N, Ide T, Saito N and Kirino T: Propentofylline potentiates induced ischemic tolerance in gerbil hippocampal neurons via adenosine receptor. J Cereb Blood Flow Metab 18: 472-475, 1998.

14. Wright HL, McCarthy HS, Middleton J and Marshall MJ: RANK, RANKL and osteoprotegerin in bone biology and disease. Curr Rev Musculoskelet Med 2: 56-64, 2009.

15. Murakami T, Yamamoto M, Ono K, Nishikawa M, Nagata N, Motoyoshi and Akatsu T: Transforming growth factor-beta1 increases mRNA levels of osteoclastogenesis inhibitory factor in osteoblastic/stromal cells and inhibits the survival of murine osteoclast-like cells. Biochem Biophys Res Commu 252: 747-752, 1998.

16. Wang $\mathrm{J}$ and Zhang JT: Total salvianolic acid against cerebral ischemia and inhibition of glutamate release. Chin J Pharmacol Toxicol 13: 197, 1999 (In Chinese)

17. Urrutia M, Fernández S, González M, Vilches R, Rojas P, Vásquez M, Kurte M, Vega-Letter AM, Carrión F, Figueroa F, et al: Overexpression of Glutamate Decarboxylase in mesenchymal stem cells enhances their immunosuppressive properties and increases GABA and nitric oxide levels. PLoS One 11: e0163735, 2016.

18. Foreman MA, Gu Y, Howl JD, Jones S and Publicover SJ: Group III metabotropic glutamate receptor activation inhibits $\mathrm{Ca} 2+$ influx and nitric oxide synthase activity in bone marrow stromal cells. J Cell Physiol 204: 704-713, 2005.

19. Sheweita SA and Khoshhal KI: Calcium metabolism and oxidative stress in bone fractures: Role of antioxidants. Curr Drug Metab 8: 519-525, 2007

20. Hayashi T1, Ina K, Maeda M and Nomura H: The effects of selective estrogen receptor modulator treatment following hormone replacement therapy on elderly postmenopausal women with osteoporosis. Nitric Oxide 24: 199-203, 2011.

21. Helfrich MH, Evans DE, Grabowski PS, Pollock JS, Ohshima H and Ralston SH: Expression of nitric oxide synthase isoforms in bone and bone cell cultures. J Bone Miner Res 12: 1108-1115, 1997.

22. Papachroni KK, Karatzas DN, Papavassiliou KA, Basdra EK and Papavassiliou AG: Mechanotransduction in osteoblast regulation and bone disease. Trends Mol Med 15: 208-216, 2009.

23. Ford H, Suri S, Nilforoushan D, Manolson M and Gong SG: Nitric oxide in human gingival crevicular fluid after orthodontic force application. Arch Oral Biol 59: 1211-1216, 2014.

24. Kalyanaraman H, Ramdani G, Joshua J, Schall N, Boss GR, Cory E, Sah RL, Casteel DE and Pilz RB: A novel, direct no donor regulates osteoblast and osteoclast functions and increases bone mass in ovariectomized mice. J Bone Miner Res 32: 46-59, 2017.

25. Aguirre J, Buttery L, O'Shaughnessy M, Afzal F, Fernandez de Marticorena I, Hukkanen M, Huang P, MacIntyre I and Polak J: Endothelial nitric oxide synthase gene-deficient mice demonstrate marked retardation in postnatal bone formation, reduced bone volume, and defects in osteoblast maturation and activity. Am J Pathol 158: 247-257, 2001.

26. Li Y, Li Y and Yang W: Preventive effects of nitroglycerine on glucocorticoid-induced osteoporosis in growing rats. J Huazhong Univ Sci Technolog Med Sci 27: 528-531, 2007.

27. Pennisi P, Clementi G, Prato A, Luca T, Martinez G, Mangiafico RA, Pulvirenti I, Muratore F and Fiore CE: $\mathrm{L}$-arginine supplementation normalizes bone turnover and preserves bone mass in streptozotocin-induced diabetic rats. J Endocrinol Invest 32: 546-51, 2009.

28. Chen Z, Yuhanna IS, Galcheva-Gargova Z, Karas RH, Mendelsohn ME and Shaul PW: Estrogen reporter alpha mediates the nongenomic activation of endothelial nitric oxide synthase by estrogen. J Clin Invest 103: 401-406, 1999.

29. Gray TK, Flynn TC, Gray KM and Nabell LM: 17 beta-estradiol acts directly on the clonal osteoblastic cell line UMR106. Proc Natl Acad Sci USA 84: 6267-6271, 1987.

30. Wang YS, Hu XY and Li YB: The pathogenesis of glucocorticoid-induced osteoporosis and prevention of experimental research. He Nan Yi Xue Yan Jiu 15: 193-204, 2006 (In Chinese).

31. Hua SM, Guan YY, Jin H and Zhang L: Compound Salvia impacting on plasma endothelin and the concentration of nitric oxide. Chin Clinical Pharmacol Therapeutics 5: 363-364, 2000 (In Chinese)

32. Wu W and Wang Y: Pharmacological actions and therapeutic applications of Salvia miltiorrhiza depside salt and its active components. Acta Pharmacol Sin 33: 1119-1130, 2012.

33. Gao XP, Xu DY, Deng YL and Zhang Y: Screening of angiotensin converting enzyme inhibitors from Salvia miltiorrhizae. Zhongguo Zhong Yao Za Zhi 29: 359-362, 2004 (In Chinese). 
34. Quan A: Fetopathy associated with exposure to angiotensin converting enzyme inhibitors and angiotensin receptor antagonists. Early Hum Dev 82: 23-28, 2006.

35. An J, Yang H, Zhang Q, Liu C, Zhao J, Zhang L and Chen B Natural products for treatment of osteoporosis: The effects and mechanisms on promoting osteoblast-mediated bone formation. Life Sci 147: 46-58, 2016.

36. Zheng $\mathrm{H}$, Yu X, Collin-Osdoby $\mathrm{P}$ and Osdoby P: RANKL stimulates inducible nitric-oxide synthase expression and nitric oxide production in developing osteoclasts. An autocrine negative feedback mechanism triggered by RANKL-induced interferon-beta via NF-kappaB that restrains osteoclastogenesis and bone resorptio. J Biol Chem 281: 15809-15820, 2006.

37. Li F, Yang Y, Zhu P, Chen W, Qi D, Shi X, Zhang C, Yang Z and Li P: Echinacoside promotes bone regeneration by increasing OPG/RANKL ratio in MC3T3-E1 cells. Fitoterapia 83: 1443-1450, 2012.

38. Yang Y, Chin A, Zhang L, Lu J and Wong RW: The role of traditional Chinese medicines in osteogenesis and angiogenesis. Phytother Res 28: 1-8, 2014.

39. Fan X, Roy E, Zhu L, Murphy TC, Ackert-Bicknell C, Hart CM, Rosen C, Nanes MS and Rubin J: Nitric oxide regulates receptor activator of nuclear factor-kappaB ligand and osteoprotegerin expression in bone marrow stromal cells. Endocrinology 145: $751-759,2004$
40. Wang FS, Wang CJ, Chen YJ, Huang YT, Huang HC, Chang PR, Sun YC and Yang KD: Nitric oxide donor increases osteoprotegerin production and osteoclastogenesis inhibitory activity in bone marrow stromal cells from ovariectomizedrats. Endocrinology 145: 2148-2156, 2004.

41. Wang S, Duan CY and Wang Q: Effects of 1, 25-droxyvitamin D_3 on nitric oxide and inducible nitric oxide synthase in peripheral blood mononu-clear cells in patients with spinal tuberculosis. China Pharmacy 19: 1474-1476, 2008 (In Chinese).

42. MacIntyre I, Zaidi M, Alam AS, Datta HK, Moonga BS, Lidbury PS, Hecker M and Vane JR: Osteoclastic inhibition: An action of nitric oxide not mediated by cyclic GMP. Proc Natl Acad Sci USA 88: 2936-2940, 1991.

43. Pratelli L, Cenni E, Granchi D, Tarabusi C, Ciapetti G and Pizzoferrato A: Cytokines of bone turnover in postmenopause and old age. Minerva Med 90: 101-109, 1999 (In Italian).

44. Abe T, Chow JW, Lean JM and Chambers TJ: Estrogen does not restore bone lost after ovariectomy in the rat. J Bone Miner Res 8: 831-838, 1993. 